\title{
https://doi.org/10.46344/JBINO.2020.v09i5b.04
}

\section{ROLE OF RASAYAN IN BALROG}

Dr. Mahesh Jadhav

Assoc Professor ,kaumarbruttya Dept. Ashvin Rural Ayurved College ,Manchihill

Email: drm.a.jadhav@gmail.com

\begin{abstract}
Attention deficit hyperactivity disorder (ADHD) manifests in childhood with symptoms of hyperactivity, impulsivity, and/or inattention. In addition, there are other secondary symptoms associated with ADHD such as insomnia, learning disabilities, and delayed language development. The symptoms affect cognitive, academic, behavioural, emotional and social functioning. ADHD is found to be more common in boys than girls. In present paper we are discussing regarding Shishu, Bala or Kumara Avastha means childhood age described by traditional science of Indian medical system, the basic features of this age group are; lack of sexual desire, sleeping tendency and Kumara Shrira, this is an age of mental and physical development. Kaumarabhrityaka, Kaumarabhritya, Kumara Tantra or Kaumarabhritya encompasses information regarding pediatric diseases (Bala Roga). The ayurveda text Kaumarabhritya not only encompasses the information regarding pediatric diseases but also emphasized diseases of genital organs which may impart to the Bala Roga. Dhatri, Stanya, Dushti may be considered as disease causative factor in Ksheerada Avastha.
\end{abstract}

Keywords: ADHD, BALAROG, RASAYAN

No: of References: 08 


\section{INTRODUCTION}

Ayurveda suggested different modalities for the prevention, diagnosis and treatment of pediatric disease. This article emphasized preventive, diagnostic and therapeutic approaches of ayurveda for the management of Bal-Roga.

The ancient literature of ayurveda reported use of herbo-mineral formulations for the treatment of various childhood diseases. The use of Rasayana therapy in Bal Rog needs great attention towards the dosing and frequency to prevent any chances of adverse reactions. to enhance longenvity, intelligence and immunity. The Rasayana Shashtra also involves use of metallic formulation along with herbs. Guduchi, Shankhpushpi, Jyotishmati, Mandookparni. etc are considered Rasayana. Rasayana boost functioning of Dhatus, Agin Srotasas and Ojus and therefore act as rejuventator. Ayruveda desecribed Rasayana also for Bal-Rog with great care since Rasayana therapy may become harmful in children if not used properly. Rasayana therapy also used as preventive remedy in children since it enhances immunity and thus protect from various infectious diseases. There are various herbometalic formulations which may be used in children for different for different therapeutic purpose such as, Svaran Bhasm, Vacha, Madhu, Ghrita, Panchgavya Ghrita, Brahmi Ghrita, Abhaya Ghrita, Abhaya Ghrita, Samvardhana Ghrita, Mandura Bhasma and Lauha Bhasma, etc. Swama Prashan is formulatuion of Swarna and herbs, Vacha and Brahmi along with honey and ghee utilized for new born baby to improve their immunity and mental health. Raw gold after rubbing on stone along with little amount of water along with honey and ghee administered to the new born baby. This type of formulation possesses

Bal-Roga: Preventive Approaches Stanya feeding from the birth develop immune system of Shishu; Stanya feeding is suggested by ayurveda for new born baby for Deha Pushti, Dhatu Vardhana and Bala Vardhana. Light liquid diet may be given after 6-8 months, heavy diet should be avoided which may cause constipation. Ayurveda also advised Phalaprashana and Annaprashana Samsakara for Bala Avastha for proper physical and mental development. Ayurveda advocated that carbohydrates, protein, fat, minerals and vitamins enriched Ahara boost immunity of growing children; thus food stuff must encompasses all essential component of balance diet.

Observation of body characters and movements of suffered child along with external symptoms. Consideration of disease associated with reproductive system of mother and Dhatri. Graham Rogas play significant role towards the disease pathogenesis in Bala Avastha. Other pathologic conditions such as; Beeja Dushti, Beejabhaga, Beejabhagavayava are few genital Vyadhi which may leads pediatric disease such as; Khandoushtha, Kuchikarnika, Jatyandha, Suchimukhi and Vaarta, etc, Diet regimen of mother during pregnancy period also play significant role towards the Bal-Roga. Nadi-Pariksha and 
Sharir-Pariksha should be involved in diagnostic approaches. Prashna Pariksha also suggests some aspect about history and prognosis of disease. Bal-Roga: Therapeutic Approaches Panchagavya Ghrita, Smriti Sagar Ras, Yogaraj Guggulu for Murcha. Shringi bhasma, Shwas kuthar ras, Talisadi Churna for Kasa. Vidangarishta, Krimikuthar ras, Vidanga Churna for Antajakrimi. Mushka Tailam, Changeri Ghrita for Guda bhramsha. Bhaskara Lavana Churna, Lavargodi Vati, Udarashula Lakshmivilas ras for Pratishyaya. Bhaskara Lavana Churna and Hingwashtak Churna for Udarashula. Rasayana therapy as rejuvenator, to facilitate immunity and as memory enhancer. Herbs such as; Shankhpushpi, Guduchi, Jyotishmati, Mandookparni etc., improve Dhatus, Agni, Srotasas and Ojus. Panchakarma therapy also play significant role in Bal Roga; since Panchakarma therapy pacify vitiated Doshas, perform detoxification and open Shrotas. Virechana control Pranavaha Sroto Vyadhi; Swasa Kasa when pitta dosha is vitiated. Nasya Karma helps in diseases which occur due to the Kapha and Vata predominance. Vamana eliminate Kapha Dosha by opening pranavaha srotastha.

Many childhood diseases occur due to the vitiation of Doshas and Panchkarma therapy help to pacify these Doshas vitiation and thus relief many disorders. It is believed that purification of body thought Panchkarma and Yoga pacifies Dosha and clear harmful toxins from the body and thus help to relive many diseases in children. Panchkarama utilizes various approaches of Shodhana such as;
Vamana, Virechan, Nasya: Vamana in children help to eliminate Kapha Dosha and thus opens pranavaha srotastha which may block due to the accumulation of Kapha in Kapha Vyadhi. Virechana may help in Pranavaha Sroto Vyadhi; Swasa Kasa where pitta dosha is predominate. Nasya Karma is useful for diseases associated with Kapha and Vata predominance. Cerebral palsy is common paediatric disorder in children. Seizures, hearing impairments and mental retardation are common features od diseases Ayruveda emphasized various treatment options for diseases including Panchkarama and yoga. It is Vata Vyadhi which involves Pankshaghat, Ekangvata, Sarvagavata, Pangu etc.

Ayurveda the basic science of traditional medical system in india consider Bal Rog under Kaumarbhritya and mentioned different therapeutic for the treatment of childhood diseases. Recently many researches utilizes Bala Panchakarma and Rasayana therapy for the management of various childhood diseases, this article described various aspect of Bala Panchakarma and Rasayana therapy with special reference to the childhood diseases. The literature suggested that Bala Panchakarma play significant role in the management of cerebal palsy, Pranavaha Srotasta and Tamaka Shwasa Panchakarma basically is a type of Shodhana Chikista. The basic principle of Kaumarabhritya involves Panchakarma in late stage of development of ayurveda science; however fixation of drug dose in and intensity of Bala Panchakarma is very important to prevent any side effect. It is 
belived that Panchakarma being Shodhana Chikista remove vitiated Doshas. The various steps of Panchakarma such as, Vamana, Virechana Basti, Niruha or Yapana Bastis and Anuvasana Basti recommended in early childhood for the management of different abnormal physiological conditions.Ayurveda believed that anti spastic, muscle relaxant and calming properties of Panchkarama and Yoga help in the management of Cerebeal palsy. Panchkarma and Yoga also emphasized role of Pranavaha Srotaashta Vyadhi is a disease of Kapha Dosha. Kapha along with Vata Dosha play major role in appearance of Panavaha Srotho Vyadhi, in which Dushitha Prana Vyau resulting Hikka and Swasa diseases, the diseases condition involves aggravation of Kapha and Vyau Swasa, Kasa, Hikka are the diseases of Prana Vahasroto Dusti, ayurveda suggested use of Panchakarma in pranavaha srotastha vyadhi not only pacify kapha and vata Dosha but it also help in excretion of harmful toxins. Shodhana through panchakarma clear accumulated Kapha and other secretion from respiratory tract and thus relief Pranavaha srotastha vyadhi.

\section{CONCLUSION}

Age from birth to 16 years described as Baalya as per Sushruta. Ayurveda depict different approaches for the prevention, diagnosis and management of Bal Roga. The traditional science explored use of different therapeutic approaches for the management of Bal-Roga such as; herbs, remedies, Rasayan \& Panchkarma but it is suggested that precaution is better than cure thus rules of Dinacharya \& Ritucharya need to be adopted in Bala Avastha to maintain discipline life style which help to retain normal health. Ayurveda also mentioned diagnostic approaches such as; consideration of Graham Rogas, NadiPariksha, Sharir-Pariksha and Prashna Pariksha as Nidana perspective of BalRoga. Ayurveda also mentioned diet regimen not only for children but also for pregnant women. This article emphasized different preventive, diagnostic and therapeutic approached of Ayurveda for the management of pediatric disease, this article may become helpful for the researches to explore novel aspect of pedantic care.

\section{REFERENCES:}

Susruta. Susurta Samhita with Nibandhasangraha Commentary by Dalhana, editiors Acharaya YT, Acharaya Narayan R. Varanasi: Choukhambha Sanskrit Sanathan; 2003, 71.

Susruta. Susurta Samhita with

Nibandhasangraha Commentary by Dalhana, editiors Acharaya YT, Acharaya Narayan R. Varanasi: Choukhambha Sanskrit Sanathan; 2003, 71

Agnivesha. Charaka Samhita with Ayurvedadipika Commentary by Chakarpanidatta, editor Acharya YT. Varanasi: Choukhambha Orientalia; 2001, 117.

Sulochana, Basic Concepts of Kaumarabhritya (Bala Roga), RA Journal of Applied Research, 2015; 10: 378. 
Kumar MA, Ojha NK, Kumar A. Rationality of Swarna Prashan in Pediatric Practice. International Journal of Ayurvedic and Herbal Medicine 2013;3:1191-1200. PEDIATRIC MANAGEMENT Prophylactic Approaches Diagnosis of Disease Therapeutic Approaches J Ayu Herb Med I Vol 3 Issue 1 I January- March 201747

Kumar A, Garai AK. A clinical study on Pandu Roga, iron deficiency anemia, with Trikatrayadi Lauha suspension in children. Journal of Ayurveda \& Integrative Medicine 2012;3(4):215-222.

Pravin M, Vedika A, Patel KS, Kori VK, Rajagopala S. An Evidence Based Review on Ayurvedic Management of Tamaka Shwasa (Bronchial Asthma), Int J Ayur Pharma Research 2015;3(2):11-18.

Jitesh V, Kumar SH. Current Trends in Ayurvedic Management of Cerebral Palsy in Children. Journal of Biological \& Scientific Opinion 2013;1 (3):282. 9. Sharma P, Sharma B, Bohra M. Management of Cerebral Palsy due to Hypoxic-Ischemic Encephalopathy, Through Panchakarma: Case Study. World Journal of Pharmaceutical Research 2015;4(10):1705. 